\title{
Rural architecture formation development principles of the traditions in Uzbekistan
}

\author{
Dilshod Sunatovich Khayrullayev ${ }^{1}$ \\ ${ }^{1} \mathrm{PhD}$ student, Samarkand State Architectural and Construction Institute, Uzbekistan
}

Email:xxayrullaev_d@umail.uz

\begin{abstract}
The traditions of rural architecture have formed and developed for centuries, taking into account the natural and climatic conditions of the territory, living conditions of the local population of the Republic of Uzbekistan. Preservation of pilgrimage places, mosques, bathhouses, national houses, historic architectural masterpieces in rural areas, which is consisted by almost half the population of the country, require a wider study of this area. Because architectural masterpieces are our national cultural heritage, our value and identity. The article gives an overview of the traditional methods as well as the harmony of modern architecture.
\end{abstract}

Keywords: kishlaks (villages), mosque, architecture, traditions, stone bathhouses, handicraft, inner and outer courtyard, modern buildings.

\section{INTRODUCTION}

In a remote past, most of the Uzbek tribes adapted to the cultivation of new land from a seminomadic lifestyle and began to engage in agriculture and horticulture. From the time their lifestyle and residential had also transformed since they moved to settled way of living but this process was carried out at a very slow pace. Craftsmanship was also developed, thus villages were emerged. It is well known in our history that by the time kishlaks (villages) became larger, cities were inhabited.

Narshakhi wrote that "They lived in tent and marquees formerly, and after a while people gathered and built buildings. The town of Bukhara hadn't emerged yet, but villages did". Those were fortified villages where the craftsmanship had been rather developed. Those were built from large raw and baked bricks and a daub wall (packed clay wall) surrounded by high duvals (walls) since which were fundamentally different from the old cellars and shelter branches of cattle breeders [5].

The vilayats (regions), districts of Uzbekistan differ in their natural-climatic conditions. At the same time, local customs and national ethnographic values have been formed in the ethnographic historical developing process. Peculiar architectural facilities, courtyards were built in each region in sight the developed historical ethnographic and natural-climatic conditions. Among them Bukhara, Khorezm, Fergana and Shakhrisabz architectural schools had been established. They, in turn, were differed in building materials, styles and the design of premises. For instance, in the Fergana Valley, resistant to the earthquake damages and to protect from the effects of air temperature, the residential places were built in double frame walls and the thickness of the roofs was up to $40 \mathrm{~cm}$. Unlike Khiva the earthquake wasn`t so high there the walls and the roofs of the building were about $10-15 \mathrm{~cm}$ thick. However, the housing architecture of Uzbekistan, not considering some of the internal features, has a common and integral denouement. This means that majority of Uzbekistan traditional houses are an integral, closed architectural complex that is characterized as it is surrounded by a fortified wall from an outer world.

An example can be found in the territory of the Pirmast array located in Gijduvan district of Bukhara region, now called the "Kurgantepa" mahalla (town block). This fortress is a historic part of the old Gijduvan, a place where people began their traditional houses in the form of an old settlement for many years. Nowadays mosques and Toshhammom (Stone bathhouse) which have been preserving in the Arabon, Kasabon streets, as well as Kurgantepa and Chorsu mahallas are still operating. Main structures of narrow streets, homesteads have been preserved in mahallas (Figures 1;2). 


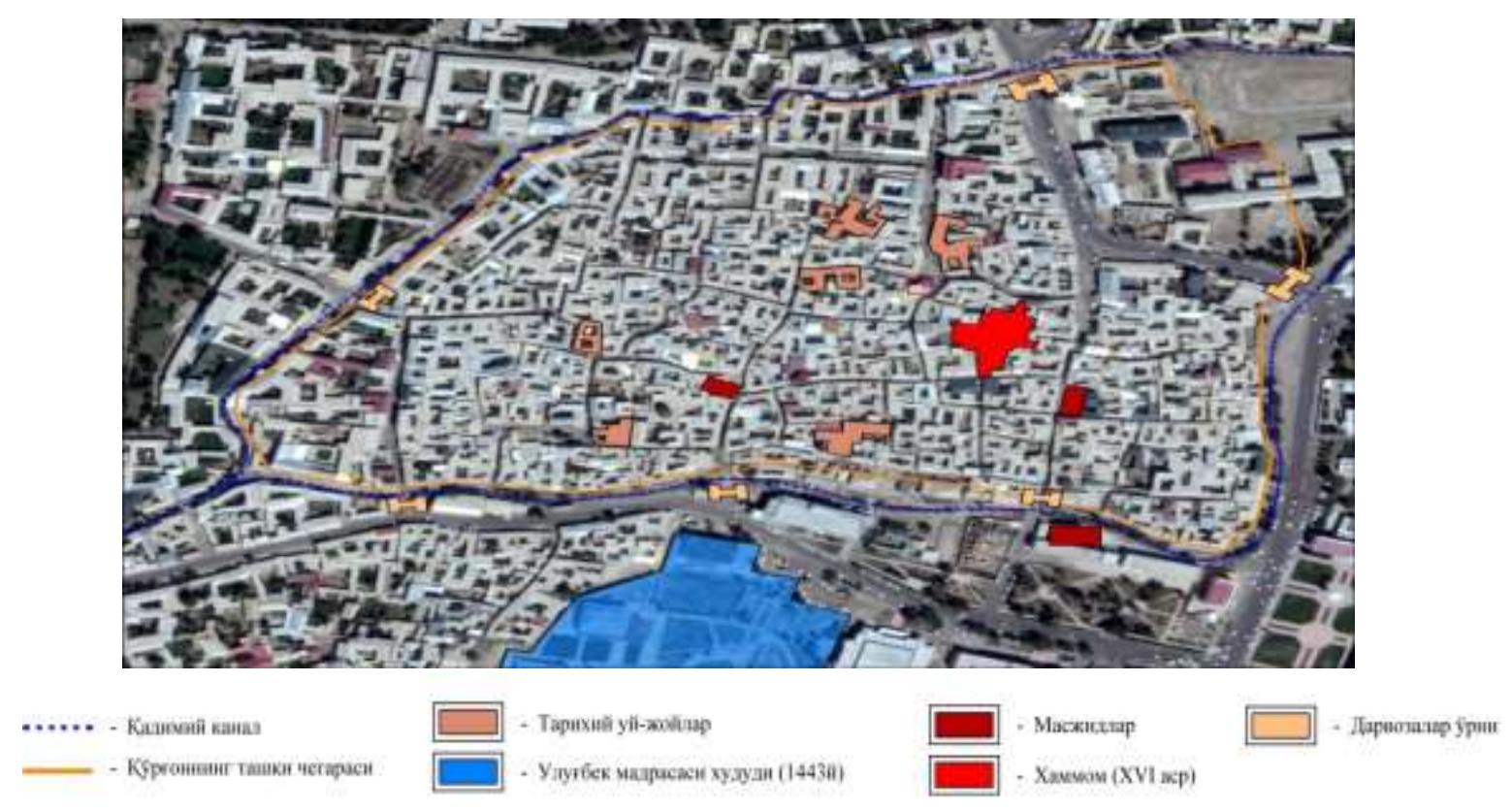

Figure 1.Territory of Kurgantepa mahalla, Gijduvon.

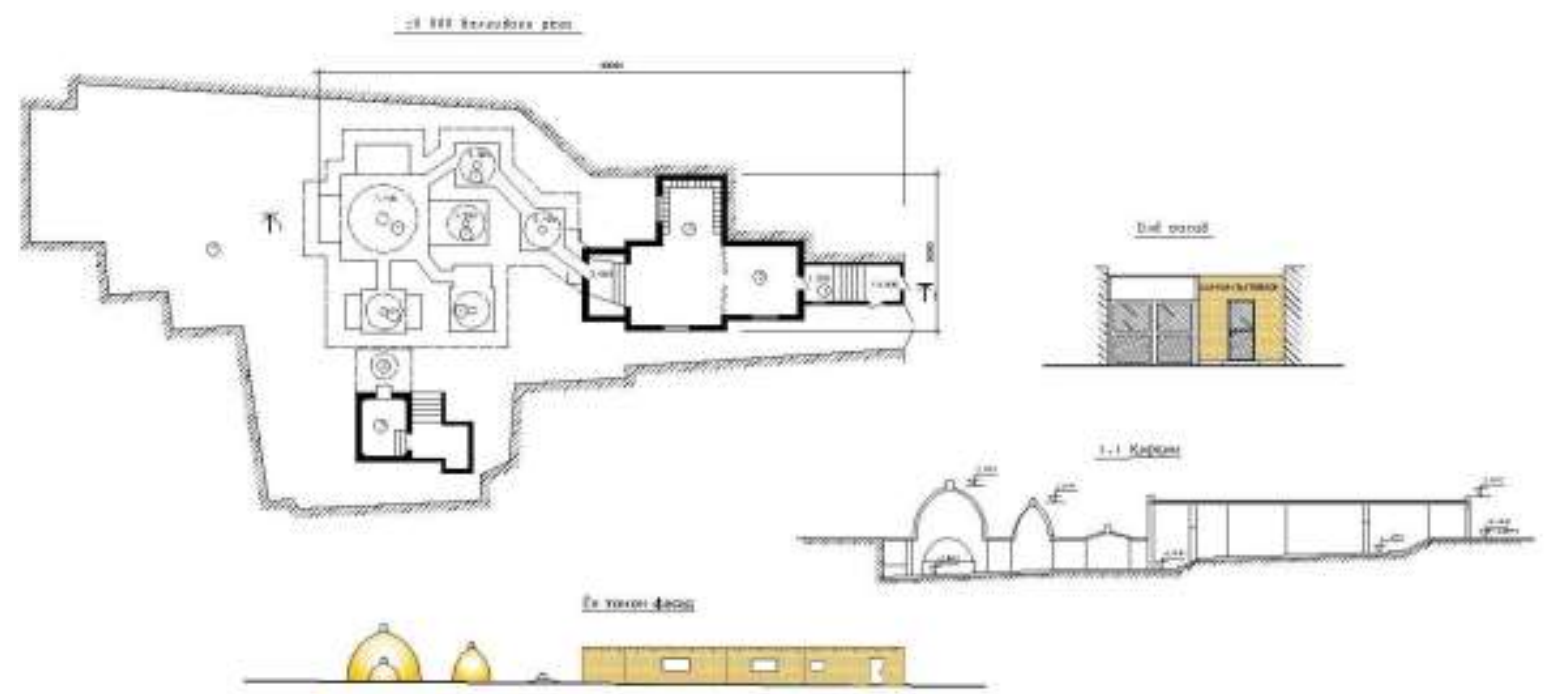

Figure 2. Building "Toshhammom" located in Kurgantepa mahalla, Gijduvan district. XVI century (author's scale and scheme).

We witnessed the fact that the names of the places, which are an important part of our national values, were changed unfounded during 70 years of Soviet Government. According to the regional data of 1924, 255 villages were registered in Gijduvan. In the archive documents there were more than 360 settlements, villages and mosques in Gijduvan in the years 1926-1930. Getting acquainted with the history of region villages, we can see that majority of places were named after the clan, state, religion and public figures, geographical names and people ethnicity by our ancestors. Later, these places were called with modern names.

There are many examples of these ancient villages, such as the village of Bofandagon (coarse calico weavers lived), the village of Zargaron (people lived who made earrings, bracelets, rings and other bijouteries), Nayman (nayman clan lived), Kassobon (butchers lived), Degreson (craftsmen lived who made pots and various households), Gadoyon (poor people lived), Toshkaron (hoe makers lived), Frishkent (seller's residences) and many other villages.

At the end of the 21st century, there were 10 mahallas, more than 2,000 households, 15 mosques, 55 private schools and higher religious schools in Gijduvan.

There were also 3 bath-houses and over 300 shops served the people. Moreover, there were 500 traders, more than 200 usurers, 10 gold-embroideries, 160 kundalmakers (kundal-one type ornament in 
applied decorative art), 150 metalworkers, more than 100 weavers, about 100 blacksmiths and 35 pottery masters, 138 carters, more than 800 day-laborers and 150 carpenters [5].

Since there were no separate mekhmonxona (living and ceremonial summer room) in middle and poor families, when strangers came, women went to their neighbors' house. There were rooms, kitchen, and storehouse and firewood rooms in the inner courtyard. Lavatory and washing rooms located either inside or outside of the yard depending on the number of the family members. And if there were more than one son in the family, they were provided with separate rooms.

Buildings, houses, as well as windows and doors of this architectural complex-all located in the inner courtyard. Prosperous family houses consisted of two parts: inner yard where women lived and outer yard - the men's residence. The inside of the yard mainly pointed at the daily life of the family where the second part had main room - guestroom adjoining buildings, crafts shops, stable, cow-house and other buildings outside (Figure 3).

Figure 3. Gijduvan District Kurgantepa Kozibon Street 20. Komilov Ibrokhim bobo (granny) house. 1920. (Author's scale and scheme). A part - the inner courtyard, 1- living room, 2- anteroom, 3- kitchen, 4- ayvan (a verandah with a flat roof supported by multi-columns or pillars) (on top of it attic), 5- terrace, 6- cellar on top of it terrace, 10- summer kitchen, 11-poygah (place esteem near door), 12- dolon (vestibule entrance courtyard) 13- lavatory. B part-outer courtyard, 7-artisan room, 8-guestroom, 9-summer room.

The design of Uzbek houses was very simple and mainly local building raw-materials were used. The main local raw materials to build houses were paksha (rammed earth, daub), adobe, wodge and pillars. Baked bricks were prepared in local handmade kilns and used mainly for the construction of large monumental buildings such as madrasahs, mosques, and bathhouses. Wood was used for covering the roof and propping the wall up and soil-clay saman (chopped straw) was mainly used in polishing the walls in the construction of buildings. In order to improve the architectural appearance of the buildings, there were takhmon (special boards for quilts lay together), shelf (alcove wall used storing different things) and to give them architectural decoration ganch (carved alabaster decoration) and gyps products were used (Figure 4).
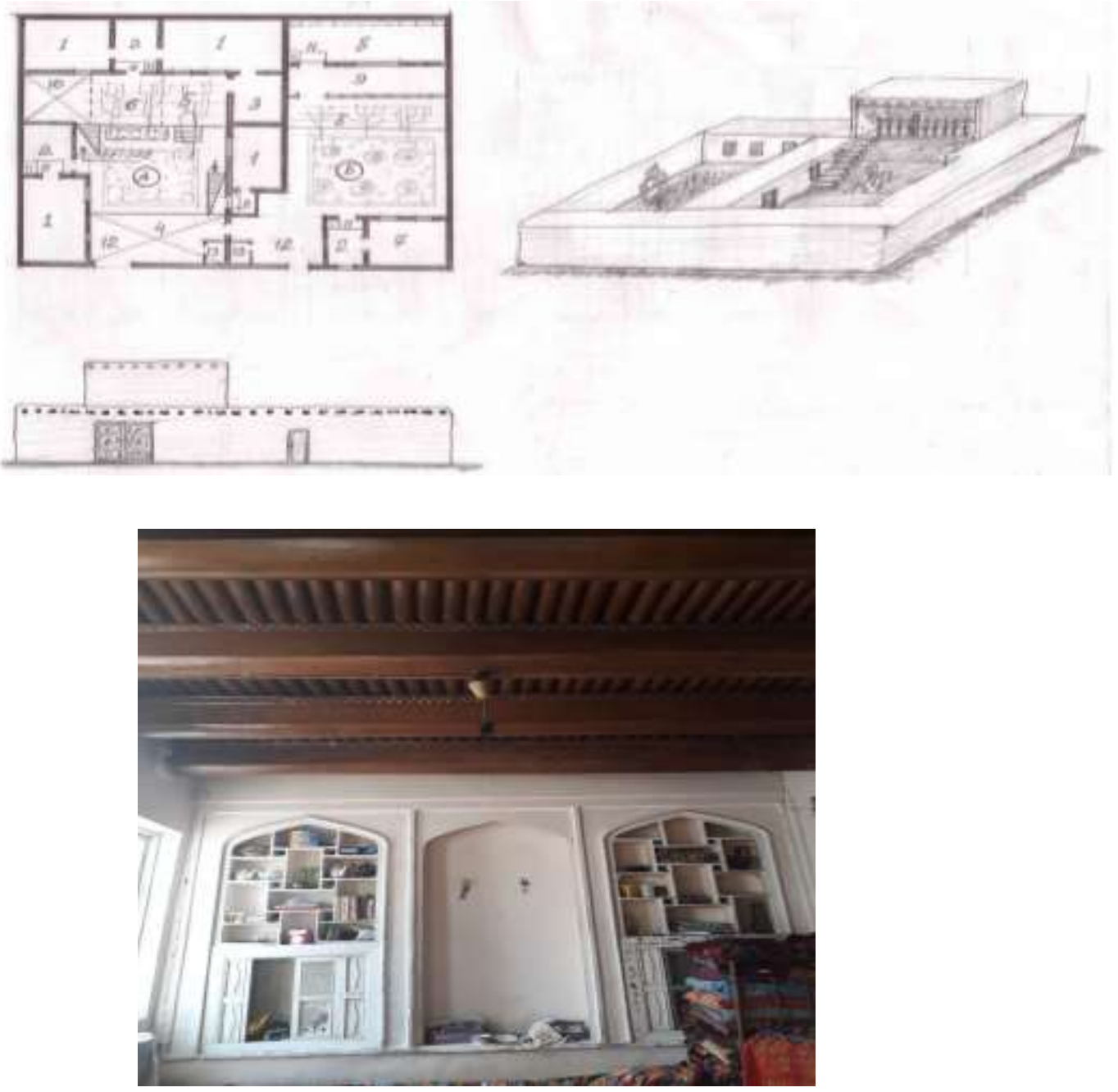


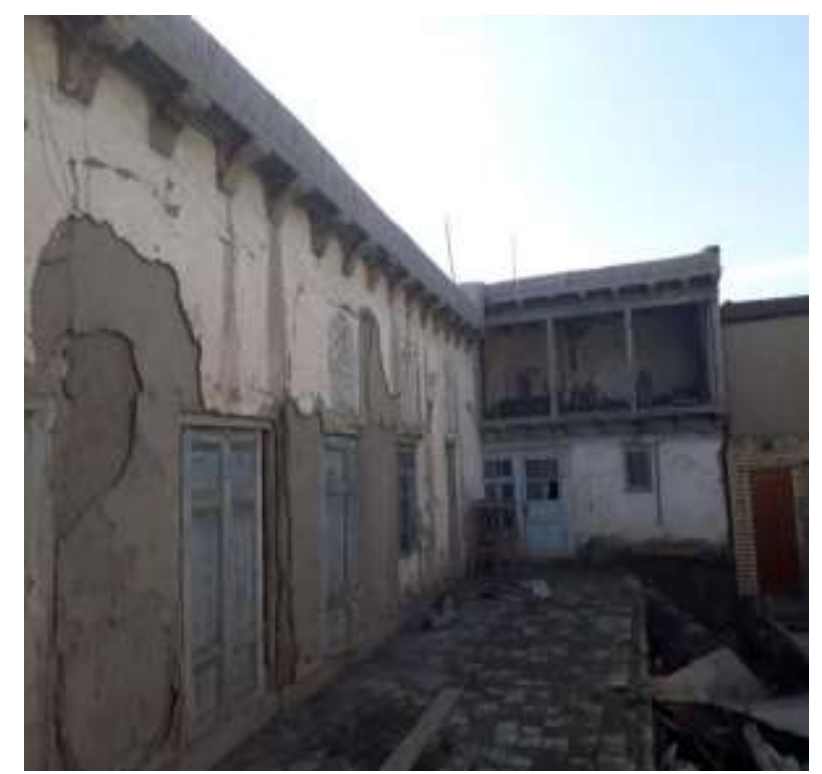

Figure 4. Inward and outward appearance of house 50, Kosibon street, Kurgantepa mahalla, Gijduvan district. 1920.

In the past, the houses were built without lying the foundation, that is, first of all the ground was flattened, watered and condensed, and then the wall was built directly on the ground. By the middle of the 19th century, the foundation of the houses wasn 't exist at all, if so, it was very short and thin that it had one-storey stone or baked brick under the wall. In a very close groundwater and salty soils, the foundation was higher, and underneath the reed laid. In the middle of the 19th century, rich traders in the big towns built houses with high foundation, half-bedded cellars and used them as a warehouse. In Bukhara, people used half-bedded cellars as residence or workshops. The floor of the house was parallel to the ground, in most cases, they made straw clays to dense ground of the floor, and rich families laid bricks on the floor. In most cases walls of the houses consisted of wooden beams that include bottom and top joining beams, furthermore, constructions of half wooden and wood pillars were used uniting and strengthen them. Wooden beams were distinguished by single linear and two-lined beams. The beams were filled with raw bricks or wodge. Raw-bricked and wodge wall houses were mainly found in the Fergana Valley, partly in the Kashkadarya (Guzar district). Wodge walls were used for the gardens of the yard in villages.

Wooden cross-beam was put on the roof of the house, over it vassa (smth.like beams, girders) were laid which created the appearance open ribbed ceiling. To make straw plaster, reed bedding was thrown over the girders and mixed with soil. Wooden or clay gutters were used to disperse snow and rainwater. The straw plaster of the roof was renewed every year, which required overhead expenses and additional work, on the other hand, it is noteworthy that in rural areas works were carried out as khashar (collective mutual aid that whole mahalla help to build a house for one of its residents) which jointly done by neighbors and relatives, and this symbolized kindness, solidarity of local people to each other.

Architectural appearance of the local people house of darwaza (gates) were different: verandah located on the second floor, gate, attic built over the entrance to the main entrance to the street and the entrance to the gate, the pillar at each side of the front gate and carved beam walls of the houses - all made exterior of the houses lively. In the big town houses carved pillars and the daub seats were placed between both sides of the gates. The gates of houses in Bukhara and Khiva were decorated with iron or copper hammers and rings.

In general, the gates in the folk architecture had given solemnity to the house composition with its elegant, beautiful style and mode and this had been a peshtak (portal- front of the building which is luxury, decorative architectural part of entrance) for residential complex. In the inner courtyard of the house, the rooms, verandahs were mainly built as one storey. Also, on the wall of the houses many had left holes to stay in touch with neighbors. Neighbors were aware of each other through the hole [11].

Living room appearance of old local houses was very simple, and the doors were right on the verandah. Threshold of the door and the door-sized wicket (kind of window), were built from the ground and the difference was that the entrance door was opened in and the wicket was out. Windows were mostly 
covered with wooden fence and bars, and were mounted on a lighting transom on top of it. Tobadon (transom, latticed opening normally located above the window or door opening) was protected by wooden or ganch fence. In the entrance of each room there was a right-angled deep place (poygah), where it was possible to remove the shoes and enter the room. In the corner there was water removal equipment - tashnov (covered pit for water flow after washing).This kind of places were covered with marble, especially in Bukhara and Samarkand, and with special ceramic lid in Khiva. Location and the style of the rooms were very simple and comfortable, that consisted of $2 \times 3$ sized rooms, and their size was determined by the number of cross-beams on the ceiling. The number of beams was always odd $(5,7,9$, etc.).

Due to the natural-climatic condition, verandah of the houses was very important. They were placed in lengthwise and angular shape. Sometimes, ordinary terraces, built on bricks or clay, were used instead of verandah. Families, over centuries, have been used to living in the rooms only during the cold months of the year, and in hot days they have been living in the yard and verandah. The yards were of different sizes, however, they were all planted greenery, and surroundings were kept tidy and neat. Grape yards were cultivated and fruit trees were planted in many yards. In scorching hot summer days, vineyard and trees casted a shadow and cool air. There was wooden trestle-bed on the ground of many courtyards, so families, mainly spent their nights there and slept in these terrace.

The ensemble was formed by the interconnection of the peculiar fragmentary pieces that intertwined with each other. Therefore, one can observe opposite striking combination of the general structure of the courtyard: on the one hand, they were built spacious, fresh; on the other hand they were kept thorough inviolability. Series of rooms and verandahs that surrounded the courtyard had amazing architectural charm. The Uzbek family could not imagine a house without yard. Since the courtyard was vital for the Uzbek family. In the scorching summer months, the yard turned into a peculiar quite green valley where there was always work to do for householders, and they could have a rest as well [6].

In 21 st century, the development of information technologies have accelerated the globalization process in the world, and human thinking horizon, their world view, lifestyle and expectations are constantly growing. And this requires a new approach to the architectural traditions and future development of our villages. These changes, of course, intensify the interest of people to the history of their ancestors, in particular the history of human civilization, which in turn it leads to the development of tourism. In this regard, tourism in Uzbekistan is developing rapidly, and the stream of tourists is increasing.

Nowadays, paying attention to another issue is becoming vital. All of us have witnessed that in our country, great attention is given to the tourism from one side, and construction of a modern style of city parts - "city" on the other. The majority of tourists travel to historical cities - Samarkand, Bukhara, Khiva, Kokand, Margilan and other places. Obviously, visitors cannot be surprised by mirrored skyscrapers and identical multi-storey buildings; they can find many compelling reasons to visit our country.

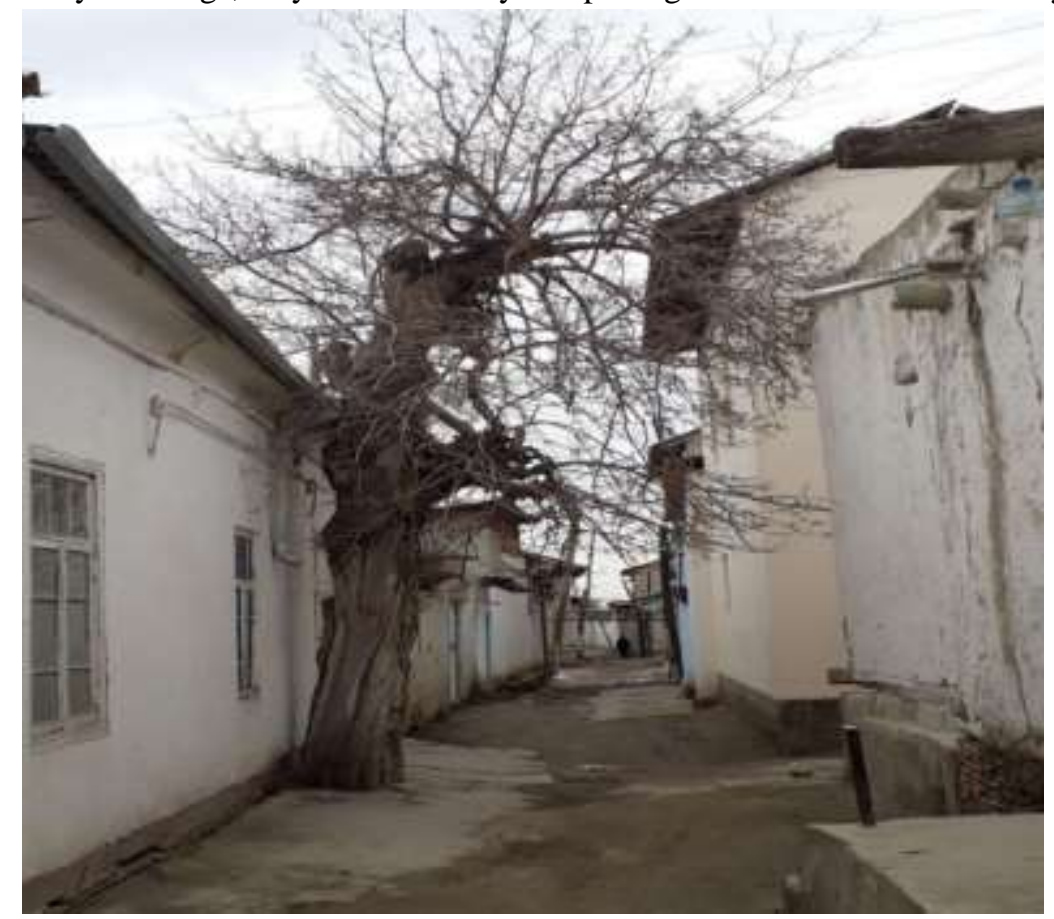




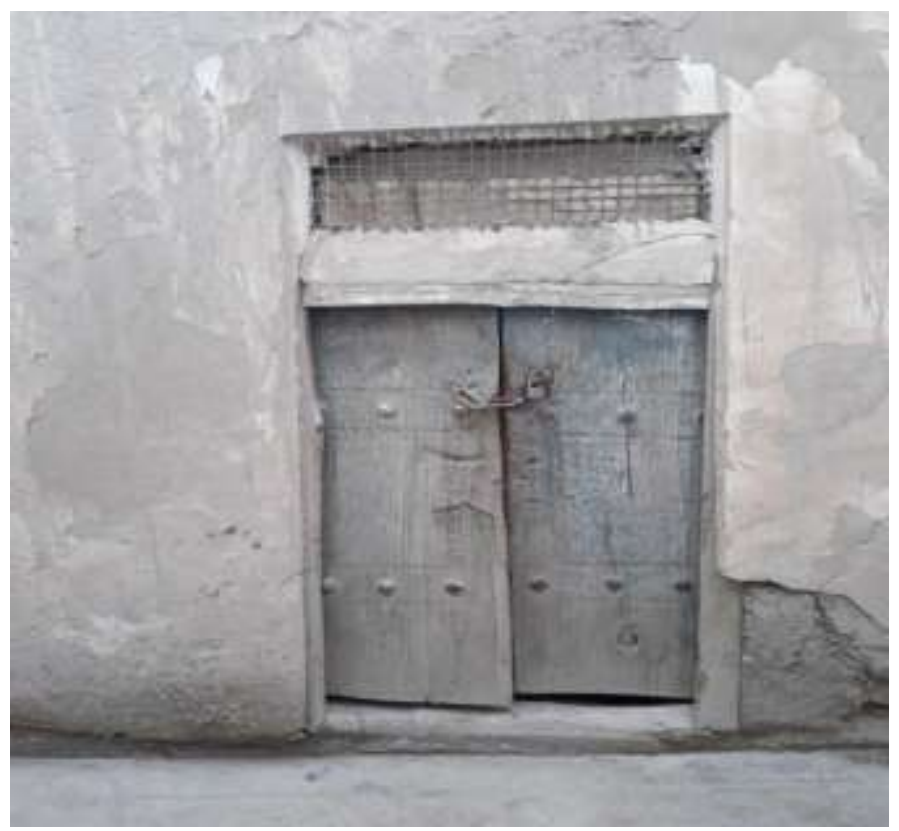

Figure 5. View of Kurgantepa mahalla, Gijduvon district.

Rich historical and cultural heritage, centuries-old traditions of people, the unique architectural monuments of ancient cities attract many tourists from abroad. Unique design, composition and technological solution of ancient masters in erection of monumental buildings amaze the imagination of spectators visiting the sights. Hospitality and generosity is unique feature of our people. Thus, each guest is surrounded by attention and care (Figure 5).

Mark Edward Rice, a translator of the novel "Days gone by" in English, lived in Uzbekistan for many years, says:

- As a person who loves your country, I can say that some buildings may be damaged. But, Eski shahar (The Old City), which has old traditional houses, attic, takhmon-shelves are more interesting to tourists. This is true (to the historical image of the city) and people live there miss and remember their old neighbors. I think designers will later realize that they are building fake ancient cities such as Dubai, and this will be similar to the world of false Disney`s tale...

Preserving traditional houses, mahallas which is becoming history today, and flourish them play an important role not only in attracting visitors, but also to deliver our cultural heritage and values for future generations. Studying the history of the ancient villages and the villages of our new time, and interpreting districts, regions, and the whole Turkestan on the basis of this history is one of the vital tasks of our scientists.

Thanks to Independence we have a chance to create our history on the basis of studying the history of our villages which considered as the cradle of our motherland, its cultural monuments, ancient relics, every hill, every village, fortress, every stone of the town, the heritage of our ancestors, values, traditions and customs. On accounting of modernization, our country, in order to be one of the developed countries, is tearing down all traditional residential districts, old mahallas, and streets. But historicity should not be lost by building new modern "cities".

\section{CONCLUSION}

It would be important to preserve historical villages, mahallas, districts where our great ancestors lived and worked, preserving them as one part of our old historical values, cultural heritage, as well as sacred place pilgrimage - is very thing that we want. And we hope that this will serve as edification for the younger generations if it serves as recognition and respect for the memory of our ancestors.

In this regard, it is advisable to pay close attention to the preservation of the main part of the old traditional residential mahallas of our ancestors in working out main plans of the future development of urban and rural settlements.

As one of the representative of this field this is our duty not only to our ancestors, but also to our future generations. 


\section{REFERENCES}

1. Akhmedov M. K. (2011). "Architectural heritage", "Science and technology" publishing, Tashkent.

2. Akhmedov M. K. (1995). "History of Central Asian architecture", "Uzbekistan" publishing, Tashkent.

3. Uralov A., Nozilov D., Turakulov Sh. (1998). "Rural houses", "Publishing house", Tashkent.

4. Abu Bakr Mukhammad Narshaxiy. (1993). "History of Bukhara", Tashkent.

5. Mukhammadjon Bakoev. (2001). "Gijduvonnoma", "New century generation", Tashkent.

6. Manakova V.N. (1990). "The artistic decoration culture of the Uzbek household", "Gafur Gulam", Tashkent.

7. Notkin I.I. (1998). № 6.22. Classification of summer premises in the people's dwelling of Uzbekistan (Khiva and Tashkent). "Construction and architecture of Uzbekistan".

8. Voronina V.L. (1959) Folk traditions of Uzbekistan's architecture, Moscow.

9. Manakova V.N. (1958) "Architectural and artistic expressiveness of traditional houses in Tashkent. - Development trend of Uzbekistan", Tashkent.

10. Pisarchik A.K. (1975). "Folk architecture of Samarkand", Dushanbe.

11. Dmitriev V.M. (1980) "Issues of using the architecture of the Uzbek national dwelling in modern practice", Tashkent.

12. Nozilov D. (1982). "Folk architecture", "Science" publishing, Tashkent. 